\title{
INDEX TO VOLUME XXI
}

\section{A}

$A d$ 'Sissoo at Susa', $B S O A S$, xIx, 2, 1957, 317, 1.5 (Ilya Gershevitch), 174.

Adhyăśayasamcodanasūtra, Note on the (D. L. Snellgrove), 620-3.

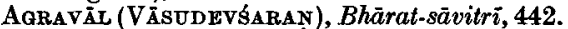

Albanian chronicle, The, of Mxit'ar Goš (C. J. F. Dowsett), 472-90.

AlLchin (F. R.), rev., 213.

AlsotT (A. N.), rev., 206-7.

almohade, Historia política del imperio. [Primera parte] (Ambrosio Huici Miranda), 190-1.

Altindische Grammatik (Jakob Wackernagel). Nachträge zu Bd. 11,1 von Albert Debrunner, 440.

Anandavardhana, Dhvanyāloka of. (Uddyota I, Uddyota II) (ed. Bishnupada Bhattacharya), 440-1.

Anandavardhana's Dhvanyāloka (tr. K. Krishnamoorthy), 440-1.

Ancient folk-literature from north-eastern Tibet (F. W. Thomas), 650-1.

Ancient Semitic civilizations (Sabatino Moscati), 437.

ANDrat (ToR), Les origines de l'Islam et le Christianisme, 673 .

ANDRZEJEWSkI (B. W.), ed., Hikmad Soomaali, by Muuse Haaji Ismaa'iil Galaal, 430-1.

Annales du Musée Royal du Congo Belge, Tervuren (Belgique). Série in $8^{\circ}$. Sciences de l'Homme. Linguistique, Vols. 3, Tom. I, 10-14 (review), 427-8.

annotation, $L$, ponctuelle de la description de voyage étonnante ... de moi Maria ter Meete. len ... (Hoorn 1748) (tr. G.-H. Bousquet and G. W. Bousquet-Mirandolle), 210.

arabe classique, L' (Henri Fleisch), 637-8.

arabe moderne, Introduction à $l$ ' (Charles Pellat), 437-8.

arabes, Les premières incursions des Vikings en Occident d'après les sources (Arne Melvinger), 211.

Arabian geographical works, Two sixteenthcentury ( $R$. B. Serjeant), 254-75.

Arabic manuscripts in the Library of the University of Leiden, Handlist of (comp. P. Voorhoeve), 628-9.

Arabic manuscripts, The, of Mount Sinai (Aziz Suryal Atiya), 672-3.

Arabic manuscripts preserved in the University Library, Ibadan, Nigeria, A catalogue of the (W. E. N. Kensdale), 673.

Arabic, The phonology of colloquial Egyptian (Richard S. Harrell), 635-7.

Arabie centrale, Expédition en (Philippe Lippens), 629-30.

'Arafat (W.), The development of a dramatic theme in the story of Khubaib b. 'Adiyy and the related poems, 15-30 ; Early crities of the authenticity of the poetry of the Sira, 453-63.
Archaeological studies in Szechwan (Chêng Tê-k'un), 200-2.

Arnots (D. W.), The classification of verbs in Tiv, 111-33.

Arya (H. W. Bailey), 522-45.

Aspiration in two Polynesian languages (G. B. Milner), 368-75.

Association of British Orientalists, $A$ select list of books on the civilizations of the Orient, 680-1.

'Atil, al-, al-hālì (Șafĩ al-Din al-Hillī), 405-7.

Atrya (AzIz SURYax), The Arabic manuscripts of Mount Sinai, 672-3.

ATKINS (GUY), rev., 434.

Atti di Krestos Samrä (ed. and tr. Enrico Cerulli), 179-80.

Averroes' Commentary on Plato's Republic (ed. and tr. E. I. J. Rosenthal), 409-10.

Avicenna, see Bakoš (Ján).

Avigad (Nahman) and Yadin (Yigael), A Genesis apocryphon, 184-5.

AYalon (David), Gunpouder and frearms in the Mamluk kingdom, 188-90.

Azerbaijan, The Turkish language of Soviet (C. G. Simpson), 439-40.

\section{B}

Batley (H. W.), Misssa suppletum, 40-7; Arya, 522-45.

BAKE (A. A.), rev., 648-9, 676.

BakoŠ (JÁN), ed. and tr., Psychologie d'Ibn Sīnā (Avicenne) d'après son ouvre Ašs-šifä', 407-9.

Batázs (ÉTIENNe), Le Traité juridique du 'Souei-chou', 651-2.

Baldwin (K. D. S.), see Gatletti (R.).

Ballhatchet (Kenneth), Social policy and social change in western India, 1817-1830, 416-17 ; rev., 443-4.

Bantoetalen, Inleiding tot de studie van de kongolese (Amaat Burssens), 427.

BASHAM (A. L.), rev., 442-3, 643-5.

BAWDEN (C. R.), rev., 202-4, 445-6, 660-2.

Baxter (Glen Wrlliam), Index to the imperial register of $t z^{6} u$ prosody, 444.

BECKINGHAM (C. F.), rev., 632-3.

Bendall (CECIL), ed., Cikshãsamuccaya, 442.

Benzing (Johannes), Die tungusischen Sprachen: Versuch einer vergleichenden Grammatik, 642-3.

Berger (MORROE), Bureaucracy and society in modern Egypt: a study of the higher civil service, 412-14.

Bergh (SIMON YAN DEN), rev., 409-10.

Berliner sugdische Texte II (Olaf Hansen), 674.

Bharata's concept of sädhārana (N. A. Jairazbhoy), 54-60.

Bhārat-sāvitrī (Vāsudevsaran Agravāl), 442.

Bhattacharya (Bishnupada), ed., Dhvanyäloka of Anandavardhana. (Uddyota 1 , Uddyota $I I), 440-1$. 
Bhatpacharya (SuKUMaR), The East India Company and the economy of Bengal from 1704 to $1740,676-7$.

Bibliography of Oceanic linguistics (comp. H. R. Klieneberger), 447-8.

Bilin, The noun in (F. R. Palmer), 376-91.

BIOBAKU (SABURI O.), The Egba and their neighbours, 1842-1872, 667-8.

Birch (CxrIL), rev., 214.

BirnbaUm (S. A.), rev., 184-5, 400-2, 625-8, 672.

Borneo, Critical survey of studies on the languages of (A. A. Cense and E. M. Uhlenbeck), $679-80$.

Borneo, Nineteenth-century (Graham Irwin), 446-7.

Bousquet (G.-H.) and Bousquet-MIRandolle (G. W.), tr., L'annotation ponctuelle de la description de voyage étonnante... de moi Maria ter Meetelen ... (Hoorn 1748), 210.

Bousquet (G.-H.) and Schacht (J.), ed., Selected works of C. Snonck Hurgronje, 439.

Bousquet-Mirandolide (G. W.), see Bousquet (G.-H.).

Bowen (Harold), see GibB (H. A. R.).

Bowen (John Charles EdwaRd), The golden . pomegranate: a selection from the poetry of the Mogul Empire in India, 1526-1858, 444.

Bownas (Groffrey), tr., Confucius, by Shigeki Kaizuka, 419-20.

Brandon (S. G. F.), rev., 183-4.

Bronze culture of ancient China (William Charles White), 657.

Brovgh (J.), Usas and Mater Matuta, 395-9 ; rev., 440-1, 441-2.

Brown (C. C.), rev., 679

Bryan (M. A.), see Tucker (A. N.).

BRYNer (EDNA), Thirteen Tibetan tankas, $677-8$.

Buddha's prolongation of life (Padmanabh S. Jaini), 546-52.

Buddhism : $a$ ' mystery religion'? (Paul Lévy), 195-7.

Buddhism in India, The decline of (R. C. Mitra), 643-5.

Buddhismus, Die Philosophie des (tr. Erich Frauwallner), 675-6.

Bulletin of the Institute of Islamic Studies, No. 1, 438-9.

Bureaucracy and society in modern Egypt : a study of the higher civil service (Morroe Berger), 412-14.

Burssens (AmaAT), Inleiding tot de studie van de kongolese Bantoetalen, 427.

Burton-Page (J.), Notes on two problems in New Indo-Aryan, 174-8 ; rev., 197-8.

\section{C}

Cachla (Pierre), Tāhā Husayn: his place in the Egyptian literary renaissance, 411-12.

Calcutta Sanskrit College Research Series, Nos. I-III, 675.

Cantera (F.) and Mrrlás (J. Ma.), Las inscripciones hebraicas de España, 625-8.

catalogue, $A$, of the Arabic manuscripts preserved in the University Library, Ibadan, Nigeria (W. E. N. Kensdale), 673.
Cense (A. A.) and Uhlen Beck (E. M.), Critical survey of studies on the languages of Borneo, 679-80.

Cerulli (Enrico), Somalia : scritti vari editi ed inediti. I, 431-2 ; Storia della letteratura etiopica, 179-80 ; ed. and tr., Atti di Krestos Samrä, 179-80.

Chan (Shau Wnna), A concise English-Chinese dictionary, 678.

Charisteria orientalia praecipue ad Persiam pertinentia (ed. Felix Tauer and others), 212-13.

ChaudhurI (Sashi Bhusan), Ethnic settlements in ancient India. Part $I, 443$.

Ch'ÂN (Jerome), The Hsien-fêng inflation, $578-86$.

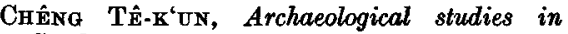
Szechwan, 200-2.

China, Bronze culture of ancient (William Charles White), 657.

China, Leaders of twentieth-century (Eugene Wu), 214.

China: new age and new outlook (Ping-chia Kuo), 202.

Chinese dictionary, A concise English- (Shau Wing Chan), 678.

Chinese Economic and Political Studies. Special Series (review), 214-15.

Chinese, Some remarks on the structure of the verb complex in Standard (H. F. Simon), 553-77.

Chinese spirit-medium cults in Singapore (Alan J. A. Elliott), 445.

Chinese texts in Tibetan transcription, A note on (Walter Simon), 334-43.

Cikshāsamuccaya (ed. Cecil Bendall), 442.

classification, The, of verbs in Tiv (D. W. Arnott), 111-33.

coinage, The, of the Tülūnids (Oleg Grabar), 631.

COLlmnder (BJöRN), Fenno-Ugric vocabulary, 415-16.

concise English-Chinese dictionary, A (Shau Wing Chan), 678.

Conferenze tenute all'Is.M.E.O. (H. Corbin and others), 680 .

Confucius, by Shigeki Kaizuka (tr. Geoffrey Bownas), 419-20.

Constitutional problems in Pakistan (Sir Ivor Jennings), 198-9.

Contemporary Indian literature : a symposium, 197-8.

Contenat (Ghorges), see Drioton (Etienne).

CorbIs (H.), and others, Conferenze tenute all'Is.M.E.O., 680 .

CoRnell (JoHn B.), see SMITH (Robert J.).

Coutumes et croyances des Falachas (ed. and tr. Wolf Leslau), 181.

Cowan (C. D.), rev., 446-7.

Critical survey of studies on the languages of Borneo (A. A. Cense and E. M. Uhlenbeck), 679-80.

Crusades, $A$ history of the. Vol. I (ed. Kenneth M. Setton), 191-2.

D

Dammane (ERNST), Studien zum Kwangali, 434.

Dayak nights, Nine (W. R. Geddes), 665. 
DebrunNer (Albert), see Wackernagel (ЈАKOB).

decline, The, of Buddhism in India (R. C. Mitra), 643-5.

Derrett (J. Duncan M.), Kuttā : a class of land-tenures in South India, 61-81; rev., 647-8.

Desai (VIbhukumar S.), ed., Rāgatattvavibodha: a work on Indian music by Srīnivāsa, 676.

development, The, of a dramatic theme in the story of Khubaib b. 'Adiyy and the related poems (W. 'Arafat), 15-30.

Dhvanyāloka, Anandavardhana's (tr. K. Krishnamoorthy), 440-1.

Dhvanyāloka of Anandavardhana. (Uddyota $I$, Uddyota II) (ed. Bishnupada Bhattacharya), 440-1.

DrNa (I. O.), see GalletTi (R.).

Diplomacy in the Near and Middle East: a documentary record (ed. J. C. Hurewitz), 192-3.

DoRE (R. P.), rev., 423-4.

Downer (G. B.), rev., 420-I.

DowsetT (C. J. F.), The Albanian chronicle of Mxit'ar Goš, 472-90.

drawing, A, of the Fatimid period (D. S. Rice), 31-9.

Drioton (ETIENNE), and others, Les religions de l'Orient ancien, 183-4.

Duchesne-Gutllemin (J.), see Drioton (ÉTIENNE).

Dumont (LovIs), Hierarchy and marriage alliance in south Indian kinship, 417-19; Une sous-caste de l'Inde du sud, 417-19.

DUPont (Pitrre), ed. and tr., La version mone du Närada-jātaka, 199-200.

dynamics, The, of a rural society (Ramkrishna Mukherjee), 677 .

\section{E}

Early critics of the authenticity of the poetry of the Sira (W. 'Arafat), 453-63.

East India Company, The, and the economy of Bengal from 1704 to 1740 (Sukumar Bhattacharya), 676-7.

Economic life of northern India in the Gupta period (Sachindra Kumar Maity), 645-7.

Economic structure of the Yüan dynasty (tr. Herbert Franz Schurmann), 654-6.

Edmonds (C. J.), Kurds, Turks and Arabs: politics, travel and research in north-eastern Iraq, 1919-1925, 414-15.

Edwards (Evangeline Dora), obituary of, $220-4$.

Egami (N.), see Corbin (H.).

Egba, The, and their neighbours, 1842-1872 (Saburi 0. Biobaku), 667-8.

EgEROD (Søren), The Lungtu dialect, 420-1.

Eliadf (M.), see Corbin (H.).

Elite communication in Samoa (Felix M. and Marie M. Keesing), 425-6.

Elliott (Alan J. A.), Chinese spirit-medium cults in Singapore, 445.

Emenead (M. B.), Kolami, a Dravidian language, 194-5.

English-Chinese dictionary, $A$ concise (Shau Wing Chan), 678.
English factories, The, in India. Vols. III-IV (New series) (Sir Charles Fawcett), 443-4.

English-Malay dictionary, An unabridged (Sir Richard Winstedt), 679.

Erdeni-yin tobči : Mongolian chronicle by Sayang Sečen (Antoine Mostaert), 202-4.

Ethnic settlements in ancient India. Part I (Sashi Bhusan Chaudhuri), 443.

etiopica, Storia della letteratura (Enrico Cerulli), 179-80.

Europe and the Turk : a pattern of alliances, 1350-1700 (Dorothy M. Vaughan), 211.

Evliy ä Chelebi, see Kredtel (Richard F.). Expédition en Arabie centrale (Philippe Lippens), 629-30.

\section{$\mathbf{F}$}

Falachas, Coutumes et croyances des (ed. and tr. Wolf Leslau), 181.

Fawcett (Sir CharLes), The English factories in India. Vols, III-IV (New series), 443-4.

FawzI (SAad ED DIN), The labour movement in the Sudan, 1946-1955, 210.

Fenno-Ugric vocabulary (Björn Collinder), 415-16.

Fernandes (Gongalo), see Wicki (Josef).

Fijian grammar (G. B. Milner), 666 .

Funtozat (J.), see Corbin (H.).

FIRTH (J. R.), Papers in linguistics, 1934-1951, $668-71$.

Five studies in Japanese politics (ed. Robert $\mathbf{E}$. Ward), 446.

FlaIsch (HenrI), L'arabe classique: esquisse d'une structure linguistique, 637-8.

FuINT (J. E.), rev., 667-8.

folktale, A spurious (W. B. Henning), 315-18.

form, The, of the object in the Uralic languages (Bo Wickman), 416.

Frauwallner (ErIch), tr., Die Philosophie des Buddhismus, 675-6.

Furber (HoLDEN), rev., 416-17.

G

Gadabuursi Somali script, The (I. M. Lewis), 134-56.

GADD (C. J.), rev., 181-3.

GalaAl (MUUSE HaAji IsmaaciL), see ANDRZEJEWSKI (B. W.).

Galletri (R.), and others, Nigerian cocoa farmers : an economic survey of Yoruba cocoa farming families, 206-7.

GEDDES (W. R.), Nine Dayak nights, 665.

Genesis apocryphon, $A$ (Nahman Avigad and Yigael Yadin), 184-5.

Geometry in Egyptian art (Else Christie Kielland), 624-5.

Georgian monarchy, The last years of the (D. M. Lang), 639-41.

Gershevitch (ILya), $A d$ 'Sissoo at Susa', $B S O A S$, XIX, 2, 1957, 317, 1. 5, 174 ; rev., 674.

Ghoshau (U. N.), Studies in Indian history and culture, 442.

GiBb (H. A. R.) and Bowen (HaRoLD), Islamic society and the West. Vol. one. Part II, 632-3. 
Gitonga of Inhambane, A study of (L. W. Lanham), 448.

GledhILL (A.), rev., 198-9.

Groli (RANimro), ed., Nepalese inscriptions in Gupta characters. Part I, 441.

golden pomegranate, The (John Charles Edward Bowen), 444.

Grabar (OLEG), The coinage of the Tülunids, 631.

Grammaire du persan contemporain (Gilbert Lazard), 638-9.

grammar, A, of Pashto (Herbert Penzl), 674.

GRAY (BASII), rev., 421-3.

Gray (John), rev., 202, 214-15.

Grenn (M. M.), Sayings of the Okonko society of the Igbo-speaking people, 157-73.

Grundriss der malayischen und indonesischen Sprache (Gerhard Kahlo), 678-9.

GrunebaUm (GuStave E. von), Kritik und Dichtkunst : Studien zur arabischen Literaturgeschichte, 673-4.

Gunlaume (A.), tr., The life of Muhammad, see Professor A. Guillaume's translation of the Sirah (R. B. Serjeant), 1-14.

Gunpowder and firearms in the Mamluk kingdom (David Ayalon), 188-90.

Guthrie (Malcolm), rev., 427-8.

\section{H}

HaAs (W.), rev., 668-71.

HAEnisch (Frich), Sinomongolische Glossare. I, 445-6.

Haggadah, The Kaufmann: facsimile edition, 401-2.

Haivrit shelanu (Haiim Rosén), 403-5.

'Hajji Ahmed, The Map of', and its makers (V. L. Ménage), 291-314.

HaLL (D. G. E.), rev., 425.

Handlist of Arabic manuscripts in the Library of the University of Leiden (comp. P. Voorhoeve), 628-9.

Hansen (OLAF), Berliner sogdische Texte II, 674.

Hansford (S. Howard), The Seligman Collection of oriental art. Vol. $1,421-3$; rev., 200-2, 657.

HaRReLl (RichaRD S.), The phonology of colloquial Egyptian Arabic, 635-7.

Harkies (LyndoN), rev., 204-5.

HaSANì ('ABD AL-RAzzĀQ aL-), Ta'rīkh alsuh̄âfa al-'Irāqiyya : al-juz' al-awwal, 212.

HeLd (G. J.), ed. and tr., Waropense teksten, 447.

Hewnina (W. B.), A spurious folktale, 315-18.

Hierarchy and marriage alliance in south Indian kinship (Louis Dumont), 417-19.

Hikmad Soomaali, by Muuse Haaji Ismaaciil Galaal (ed. B. W. Andrzejewski), 430-1.

Hippologica Accadica (Armas Salonen), 181-3.

Historia politica del imperio almohade. [Primera parte] (Ambrosio Huici Miranda), 190-1.

Historical atlas of the Muslim peoples (comp. R. Roolvink), 410-11.

history, A, of the Crusades. Vol. I (ed. Kenneth M. Setton), 191-2.

Hoenerbach (WILHEIm), ed., Die vulgärarabische Poetik al-Kitâb al-'Átil al-hãlì wal-

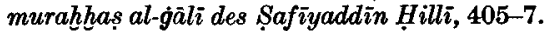

Holt (P. M.), The Sudanese Mahdia and the outside world : 1881-9, 276-90; rev., 192-3, 438.

HombURGFr (L.), Les langues négro-africaines et les peuples qui les parlent. Nouvelle édition, 448.

HooykaAs (C.), rev., 679-80.

Hopkins (J. F. P.), rev., 190-1.

HoURANI (ALBERT), rev., 633-5.

Hrbek (IvaN), see Tauer (Felix).

Hsien-fêng inflation, The (Jerome $\mathrm{Ch}^{\prime}$ ên), $578-86$.

Hutci Mrranda (Ambrosio), Historia política del imperio almohade. [Primera parte], 190-1.

Hulsewt (A. F. P.), Remnants of Han law. Vol. I, 652-4.

Humbertchadde (P.), see Corbin (H.).

HuntingFord (G. W. B.), rev., 205-6.

hwong-h $\delta a$, Varieties of (Henry McAleavy), 608-19.

HoRfwitz (J. C.), ed., Diplomacy in the Near and Middle East: a documentary record, 192-3.

IbN Rusho, see Rosenthal (E. I. J.).

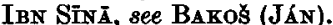

Igbo-speaking people, Sayings of the Okonko society of the (M. M. Green), 157-73.

Im Reiche des goldenen Apfels : des tirkischen Weltenbummlers Evliyấ Celebi denkwiurdige Reise ... anno 1665 (ed. and tr. Richard F. Kreutel), 211.

Index to the imperial register of $t z^{\mathrm{c}} u$ prosody (Glen William Baxter), 444.

India, The personality of (BendapudiSubbarao), 213.

Indian history and culture, Studies in (U. N. Ghoshal), 442.

Indian literature, Contemporary, 197-8.

Indo-Aryan, Notes on two problems in New (J. Burton-Page), 174-8.

Indo-Iranian Reprints, II-III, 674.

Indonesian sociological studies, part two (B. Schrieke), 425.

indonesischen Sprache, Grundriss der malayischen und (Gerhard Kahlo), 678-9.

Inleiding tot de studie van de kongolese Bantoetalen (Amaat Burssens), 427.

inscripciones hebraicas, Las, de España (F. Cantera and J. Ma. Millás), 625-8.

Institute of Islamic Studies, Bulletin of the, No. 1, 438-9.

INTERnational AFrican INstitute, Linguistic survey of the northern Bantu borderland. Vol. one, 434-5.

Introduction à l'arabe moderne (Charles Pellat), 437-8.

Irwin (GrahaM), Nineteenth-century Borneo, 446-7.

Islam and Russia : a detailed analysis of $A n$ outline of the history of Islamic studies in the USSR by N. A. Smirnov, with an introduction by Ann K. S. Lambton, 211-12.

Islam in modern history (Wilfred Cantwell Smith), 633-5.

Islam, War and peace in the law of (Majid Khadduri), 438. 
Islamic art and archaeology : a register of work published in the year 1954 (comp. J. D. Pearson and D. S. Rice), $193-4$.

Islamic metal work, Studies in, VI (D. S. Rice), 225-53.

Islamic society and the West. Vol. one. Part II (H. A. R. Gibb and Harold Bowen), 632-3.

Islamic Studies, Bulletin of the Institute of, No. 1, 438-9.

Israel : the emergence of a new nation (Oscar Kraines), 210.

Iteso, The (J. C. D. Lawrance), 205-6.

ITTMANN (JoHANNES), Volkskundliche und religiöse Begriffe im nördlichen Waldland von Kamerun, 448.

\section{$\mathbf{J}$}

Jani (PADMana Bh S.), On the theory of two Vasubandhus, 48-53 ; Buddha's prolongation of life, $546-52$.

JAIRAZBHOY (N. A.), Bharata's concept of sādhärana, 54-60.

JAMES ('T. G. H.), rev., 624-5.

Japanese politics, Five studies in (ed. Robert $\mathbf{E}$. Ward), 446.

Japanese thrust, The, into Siberia, 1918 (James William Morley), 662-3.

Japanese villages, Two (Robert J. Smith and John B. Cornell), 423-4.

JennnNas (Sir Ivor), Constitutional problems in Pakistan, 198-9.

Johnston, Sir Harry, \& the scramble for Africa (Roland Oliver), 432-4.

\section{$\mathbf{K}$}

KaHLo (GerhaRD), Grundriss der malayischen und indonesischen Sprache, 678-9.

Kaizuka (Shigeri), see Bownas (Geoffrey).

Kaufmann Haggadah, The : facsimile edition, 401-2.

Kenstna (Felix M. and Marte M.), Elite communication in Samoa, 425-6.

KENSDALE (W. E. N.), A catalogue of the Arabic manuscripts preserved in the University Library, Ibadan, Nigeria, 673.

KHADDURI (MAJID), War and peace in the law of Islam, 438.

Khubaib b. 'Adiyy and the related poems, The development of a dramatic theme in the story of (W. 'Arafat), 15-30.

Kuglland (Else Christie), Geometry in Egyptian art, 624-5.

Kitāb al-shifā' (Ibn Sīnā), 407-9.

$K i$-Vumba, a dialect of the southern Kenya coast (H. E. Lambert), 204-5.

KITRNEB FRRGR (H. R.), comp., Bibliography of Oceanic linguistics, 447-8.

Köhlirr (Oswin), rev., 428-30.

Kolami, a Dravidian language (M. B. Emeneau), $194-5$.

KRAINFS (Oscar), Israel : the emergence of a new nation, 210.

Krestos Samrā, Atti di (ed. and tr. Enrico Cerulli), 179-80.
KREUThL (RICHARD F.), ed. and tr., Im Reiche des goldenen Apfels: des tiurkischen Weltenbummlers Evliyá Çelebi denkwürdige Reise... . anno $1665,211$.

K RISHNAMOORTHY (K.), tr., Anandavardhana's Dhvanyāloka, 440-1.

Kritik und Dichtkunst : Studien zur arabischen Literaturgeschichte (Gustave E. von Grunebaum), 673-4.

KubfČrova (V̆̌Ra), see TAUkr (Fhi,IX).

Kuo (Ping-chia), China: new age and new outlook, 202.

Kurds, Turks and Arabs : politics, travel and research in north-eastern Iraq, 1919-1925 (C. J. Edmonds), 414-15.

Kusemai, The structure of (P. G. O'Neill), 100-10.

$K u t t \bar{a}$ : a class of land-tenures in South India (J. Duncan M. Derrett), 61-81.

Kuangali, Studien zum (Ernst Dammann), 434.

Kyaikmaraw inscriptions, The (H. L. Shorto), 361-7.

\section{I}

labour movement, The, in the Sudan, 1946-1955 (Saad ed Din Fawzi), 210.

LAMBERT (H. E.), Ki-Vumba, a dialect of the southern Kenya coast, 204-5.

LaMBTON (ANN K. S.), see Islam and Russia.

LaNa (D. M.), The last years of the Georgian monarchy, 639-41; rev., 185-7, 631.

Language in relation to a unified theory of the structure of human behavior. Parts I-II. Preliminary edition (Kenneth L. Pike), 207-10.

langues négro-africaines, Les (L. Homburger), 448.

LANHAM (L. W.), A study of Gitonga of Inhambane, 448.

Lao Tzŭ, The treatment of opposites in (D. C. Lau), 344-60.

last years, The, of the Georgian monarchy (D. M. Lang), 639-41.

LAU (D. C.), The treatment of opposites in Lao Tzŭ, 344-60 ; rev., 419-20.

LAWRANCE (J. D. C.), The Iteso : fifty years of change in a Nilo-Hamitic tribe of Uganda, 205-6.

LAZARD (GIIBERT), Grammaire du persan contemporain, 638-9.

Leaders of twentieth-century China: an annotated bibliography (Eugene Wu), 214.

Legende, Die, von Sunahsepa (Friedrich Weller), 675.

LFSLAU (WoLF), ed, and tr., Coutumes et croyances des Falachas, 181.

LEVy (PAUL), Buddhism : a ' mystery religion'?, 195-7.

LEWIS (B.), rev., 412-14.

LEWIS (I. M.), The Gadabuursi Somali script, 134-56.

Linguistic survey of the northern Bantu borderland. Vol. one (International African Institute), 434-5.

Linguistic survey of the northern Bantu borderland. Vol. two (Irvine Richardson), 436. 
Linguistic survey of the northern Bantu borderland. Vol. four (A. N. Tucker and M. A. Bryan), 666-7.

LIPPENS (PhIIPPE), Expédition en Arabie centrale, 629-30.

LOEWENTHAL (RUDOLF), The Turkic languages and literatures of Central Asia: a bibliography, 642.

Lomóngo, Syntaxis van het (Albert Jozef de Rop), 448.

Lungtu dialect, The (Søren Egerod), 420-1.

\section{$\mathbf{M}$}

Maasai grammar, A, with vocabulary (A. N. Tucker and J. Tompo Ole Mpaayei), 428-30.

McAleavy (HenRy), Varieties of hwo ng. hóa : a problem of Vietnamese law, 608-19.

MacKenzie (D. N.), Pashto verse, 319-33.

Mahdia, The Sudanese, and the outside world: 1881-9 (P. M. Holt), 276-90.

MatTy (Sachindra Kumar), Economic life of northern India in the Gupta period, 645-7.

Malay dictionary, An unabridged English(Sir Richard Winstedt), 679.

malayischen und indonesischen Sprache, Grundriss der (Gerhard Kahlo), 678-9.

Mamluk kingdom, Gunpouder and firearms in the (David Ayalon), 188-90.

'Map of Hajji Ahmed, The', and its makers (V. L. Ménage), 291-314.

MASTER (AlFRED), rev., 194-5.

Masti (J.), see Corbir (H.).

Materials on Muslim education in the Middle Ages (A. S. Tritton), 630-1.

Mayer (Adrian C.), rev., 417-19.

MAYER (L. A.), rev., 193-4.

MeEtelen (Maria TER), see Bodsquet (G.-H.).

Melvinger (ARNE), Les premières incursions des Vikings en Occident d'après les sources arabes, 211.

Ménage (V. L.), 'The Map of Hajii Ahmed' and its makers, 291-314.

Menges (KaRL H.), Some remarks on Oyrot morphology, 491-521.

Minuás (J. Ma.), see Cantera (F.).

Mirner (G. B.), Aspiration in two Polynesian languages, 368-75; Fijian grammar, 666 ; rev., 425-6, 665 .

Minard (Armand), Trois énigmes sur les Cent Chemins. Tom. II, 441-2.

MiNORSKY (V.), rev., 639-41.

Missa suppletum (H. W. Bailey), 40-7.

Mitchell (T. F.), rev., 207-10, 635-8.

Mitra (R. C.), The decline of Buddhism in India, 643-5.

mone, La version, du Nārada-jātaka (ed. and tr. Pierre Dupont), 199-200.

Mongolian monuments, The, in hP'ags-pa script (Nicholas Poppe), 660-2.

Moore (Charles A.), see Radhakrishnan (Sarvepalut).

MoRley (JaMeS Winliam), The Japanese thrust into Siberia, 1918, 662-3.

Moscati (Sabatino), I predecessori d'Israele, 400 ; Ancient Semitic civilizations, 437.

Mostaert (ANToIne), Erdeni-yin tobéi : Mongolian chronicle by Sayang Sečen, 202-4.
Modue (A. C.), Quinsai, with other notes on Marco Polo, 656-7.

Moyse-Bantlett (H.), rev., 432-4.

MPaAyei (J. ToMpo OLE), see TuCkER (A. N.). Muhammad at Medina (W. Montgomery Watt), 187-8.

MUKHERJEE (RAMKRISHNA), The dynamics of a mural society : a study of the economic structure in Bengal villages, 677.

Muslim education in the Middle Ages, Materials on (A. S. Tritton), 630-1.

Muslim history, Sidelights on (A. S. Tritton), 464-71.

Muslim Modernism in the Indo-Pakistan subcontinent (F. Rahman), 82-99.

Muslim peoples, Historical atlas of the (comp. R. Roolvink), 410-11.

Muslim Spain, The Old Testament in (A. S. Tritton), 392-5.

Mxit'ar Goš, The Albanian chronicle of (C. J. F. Dowsett), 472-90.

Mysticism, sacred and profane (R. C. Zaehner), 185-7.

\section{$\mathrm{N}$}

Nätya, nrtta and nrtya : their meaning and relation (K. M. Varma), 648-9.

Nāyakas, The, of Ilkkēri (K. D. Swaminathan), $647-8$.

Near and Middle East, Diplomacy in the (ed. J. C. Hurewitz), 192-3.

NEBESKY-WoJKoWTTZ (RENE DE), Oracles and demons of Tibet, 649-50.

Nepalese inscriptions in Gupta characters. Part I (ed. Raniero Gnoli), 441.

New Indo-Aryan, Notes on two problems in (J. Burton-Page), 174-8.

Nigerian cocoa farmers : an economic survey of Yoruba cocoa farming families (R. Galletti and others), 206-7.

Nine Dayak nights (W. R. Geddes), 665.

Nineteenth-century Borneo (Graham Irwin), 446-7.

Note on the Adhyãsayasamcodanasūtra (D. L. Snellgrove), 620-3.

note, A, on Chinese texts in Tibetan transcrip. tion (Walter Simon), 334-43.

Notes on two problems in New Indo-Aryan (J. Burton-Page), 174-8.

noun, The, in Bilin (F. R. Palmer), 376-91.

O

Oceanic linguistics, Bibliography of (comp. H. R. Klieneberger), 447-8.

Old Testament, The, in Muslim Spain (A. S. Tritton), 392-5.

Oliver (Roland), Sir Harry Johnston \& the scramble for Africa, 432-4.

On the theory of two Vasubandhus (Padmanabh S. Jaini), 48-53.

O'Nercl (P. G.), The structure of Kusemai, 100-10.

Oracles and demons of Tibet (René de NebeskyWojkowitz), 649-50.

Orient, $A$ select list of books on the civilizations of the (Association of British Orientalists), $680-1$. 
Oriental despotism: a comparative study of total power (Karl A. Wittfogel), 657-60.

origines, Les, de l'Islam et le Christianisme (Tor Andrae), 673.

Oyrot morphology, Some remarks on (Karl H. Menges), 491-521.

\section{$\mathbf{P}$}

Pakistan, Constitutional problems in (Sir Ivor Jennings), 198-9.

Palmer (F. R.), The noun in Bilin, 376-91.

Papers in linguistics, 1934-1951 (J. R. Firth), 668-71.

PARRY (V. J.), rev., 188-90, 191-2.

Pashto, A grammar of (Herbert Penzl), 674.

Pashto verse (D. N. MacKenzie), 319-33.

Pearson (J. D.), rev., 628-9.

Pearson (J. D.) and Rrce (D. S.), comp., Islamic art and archaeology : a register of work published in the year 1954, 193-4.

Pellat (Chardes), Introduction à l'arabe moderne, 437-8.

Penzl (Herbert), A grammar of Pashto, 674. persan contemporain, Grammaire du (Gilbert Lazard), 638-9.

personality, The, of India (Bendapudi Subbarao), 213.

Phitrps (C. H.), see Edwards (Evangeline DORA).

Philosophie, Die, des Buddhismus (tr. Erich Frauwallner), 675-6.

phonology, The, of colloquial Egyptian Arabic (Richard S. Harrell), 635-7.

Pike (Kenneth L.), Language in relation to a unified theory of the structure of human behavior. Parts I-II. Preliminary edition, 207-10.

Pitchar (Donald), rev., 410-11.

Polynesian languages, Aspiration in two (G. B. Milner), 368-75.

POPPE (NICHOLAS), The Mongolian monuments in hP'ags-pa script, 660-2.

predecessori, I, d'Israele (Sabatino Moscati), 400.

premières incursions, Les, des Vikings en Occident d'après les sources arabes (Arne Melvinger), 211.

Psychologie d'Ibn Sinä (Avicenne) d'après son

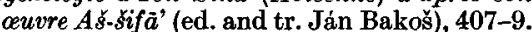

Pulleyblank (E. G.), rev., 657-60.

\section{$\mathbf{Q}$}

Quinsai, with other notes on Marco Polo (A. C. Moule), 656-7.

Qumran studies (Chaim Rabin), 672.

\section{$\mathbf{R}$}

RaBIN (ChaIM), Qumran studies, 672.

Radhakrishnaw (Sarvepalil) and Moore (Charles A.), ed., $A$ source book in Indian philosophy, 675-6.

Răgatattvavibodha : a work on Indian music by Śrinivảsa (ed. Vibhukumar S. Desai), 676.

Rahman (F.), Muslim Modernism in the IndoPakistan sub-continent, 82-99 ; rev., 407-9. religions, Les, de l'Orient ancien (Étienne Drioton and others), 183-4.

Remnants of Han law. Vol. I (A. F. P. Hulsewé), $652-4$.

Rice (D. S.), A drawing of the Fatimid period, 31-9; Studies in Islamic metal work-VI, 225-53.

Rice (D. S.), see Prarson (J. D.).

RICHARDgon (IRVINE), Linguistic survey of the northern Bantu borderland. Vol. two, 436.

RoBINs (R. H.), rev., 666.

RoBSON (JAMES), rev., 630-I.

RooLvINK (R.), comp., Historical atlas of the Muslim peoples, 410-11.

RoP (ALBERT JozeF DE), Syntaxis van het Lomóngo, 448.

Rosen (HAIM), Haivrit shelanu, 403-5.

Rosenthat (E. I. J.), ed. and tr., Averroes' Commentary on Plato's Republic, 409-10.

RYPRa (JaN), see TaUer (Felix).

\section{S}

ȘAfì aL-Dīn aL-Hirlì, see Hoknerbach (WIHHELM).

Sarang Sečen, see Mostafert (Antorne).

Salonen (ARMas), Hippologica Accadica, $181-3$.

Samoa, Elite communication in (Felix M. and Marie M. Keesing), 425-6.

Samrā, Atti di Krestos (ed. and tr. Enrico Cerulli), 179-80.

SAVORY (R. M.), rev., 638-9.

Sayings of the Okonko society of the Igbospeaking people (M. M. Green), 157-73.

Schacht (J.), see Bousquet (G.-H.).

Schapera (I.), rev., 680.

SCHEIBER (AleXaNDER), The Kaufmann Haggadah, 401-2.

SCHRIEKE (B.), Indonesian sociological studies, part two, 425 .

Schrift, Die, des P. Gonçalo Fernandes S.J. über die Brahmanen und Dharma-Sastra (Madura 1616) (Josef Wicki), 213-14.

SchurmanN (HerberT Franz), tr., Economic structure of the Yiuan dynasty, 654-6.

SEgAL (J. B.), rev., 400, 403-5.

select list of books, $A$, on the civilizations of the Orient (Association of British Orientalists), $680-1$.

Selected works of $C$. Snouck Hurgronje (ed. G.-H. Bousquet and J. Schacht), $\mathbf{4 3 9}$.

Seligman Collection, The, of oriental art. Vol. I (S. Howard Hansford), 421-3.

Semitic civilizations, Ancient (Sabatino Moscati), 437.

SerJgant (R. B.), Professor A. Guillaume's translation of the Sirah, 1-14; Two sixteenth-century Arabian geographical works, $254-75$; rev., 187-8, 405-7, 411-12, 414-15, 437-8, 629-30.

Setton (Kenneth M.), ed., $A$ history of the Crusades. Vol. I, 191-2.

Sнorto (H. L.), The Kyaikmaraw inscriptions, 361-7; rev., 199-200.

Siam under Rama III, 1824-1851 (Walter F. Vella), 663-5.

Sidelights on Muslim history (A. S. Tritton), 464-71. 
Sifra or Torat kohanim according to Codex Assemani LXVI, 400-1.

Srmmonds (E. H. S.), rev., 663-5.

Srmon (H. F:), Some remarks on the structure of the verb complex in Standard Chinese, $553-77$.

Srmon (Walter), A note on Chinese texts in Tibetan transeription, $334-43$; rev., 678 .

Stmon (Walter), see Edwards (Evangeline DoRA).

Smpson (C. G.), The Turkish language of Soviet Azerbaijan, 439-40.

Stmpson (C. G.), see Some remarks on Oyrot morphology (Karl H. Menges), 491-521.

Sinomongolische Glossare. I (Erich Haenisch), 445-6.

SrNoR (D.), rev., 415-16, 642-3.

Sir Harry Johnston \& the scramble for Africa (Roland Oliver), 432-4.

Sira, Early critics of the authenticity of the poetry of the (W. 'Arafat), 453-63.

Sirah, Professor A. Guillaume's translation of the (R. B. Serjeant), 1-14.

'Sissoo at Susa', $A d$ (Ilya Gershevitch), 174.

Smmrnov (N. A.), see Islam and Russia.

Smith (Robert J.) and CoRNell (JoHn B.), Two Japanese villages, 423-4.

SMITh (WILFRED CANTWhLL), Islam in modern history, 633-5.

SNelugrove (D. L.), Note on the Adhyäsayasamcodanasūtra, 620-3 ; rev., 649-51, 677-8.

Snouck Hurgronje, Selected works of $C$. (ed. G.-H. Bousquet and J. Schacht), 439.

Swoxall (R. A.), rev., 666-7.

Social implications of industrialization and urbanization in Africa south of the Sahara, 680.

Social policy and social change in western India, 1817-1830 (Kenneth Ballhatchet), 416-17.

sogdische Texte, Berliner, II (Olaf Hansen), 674.

Somali seript, The Gadabuursi (I. M. Lewis), 134-56.

Somalia: scritti vari editi ed inediti. I (Enrico Cerulli), 431-2.

Some remarks on Oyrot morphology (Karl H. Menges), 491-521.

Some remarks on the structure of the verb complex in Standard Chinese (H. F. Simon), 553-77.

Somkrvel. (D. C.), see Toynbee (ARnold J.). Soomaali, Hikmad, by Muuse Haaji Ismaasiil Galaal (ed. B. W. Andrzejewski), 430-1.

source book, A, in Indian philosophy (ed. Sarvepalli Radhakrishnan and Charles $A$. Moore), 675-6.

sous-caste, Une, de l'Inde du sud (Lonis Dumont), 417-19.

spurious folktale, A (W. B. Henning), 315-18.

Ŝ́rîntvãsa, see Desat (Vibhukumar S.).

Storia della letteratura etiopica (Enrico Cerulli), 179-80.

StorRy (RICHARD), rev., 662-3.

structure, The, of Kusemai (P. G. O'Neill), 100-10.

Studien zum Kwangali (Ernst Dammann), 434.

Studies in Indian history and culture (U. N. Ghoshal), 442.

Studies in Islamic metal work-VI (D. S. Rice), 225-53. study, A, of Gitonga of Inhambane (L. W. Lanham), 448.

study of history, $A$ (Arnold J. Toynbee). Abridgement of Vols. VII-X by D. C. Somervell, 439.

SubBarao (BendardDI), The personality of India, 213.

Sudan, The labour movement in the, 1946-1955 (Saad ed Din Fawzi), 210.

Sudanese Mahdia, The, and the outside world : 1881-9 (P. M. Holt), 276-90.

Sunahsepa, Die Legende von (Friedrich Weller), 675.

Swamtnathan (K. D.), The Nāyakas of Ikkēri, 647-8.

Syntaxis van het Lomßngo (Albert Jozef de Rop), 448.

Szechwan, Archaeological studies in (Chêng Tê-k'un), 200-2.

$\mathbf{T}$

Tāhä Husayn : his place in the Egyptian literary renaissance (Pierre Cachia), 411-12.

Tāmbralinga, (O. W. Wolters), 587-607.

Ta'rikkh al-suhāfa al-'Irāqiyya : al-juz' al-awwal ('Abd al-Razzāq al-Hiasani), 212.

TaUer (FruIX), and others, ed. Charisteria orientalia praecipue ad Persiam pertinentia. [Ioanni Rypka...hoc volumen sacrum], 212-13.

Thirteen Tibetan tankas (Edna Bryner), 677-8.

Thомas (F. W.), Ancient folk-literature from north-eastern Tibet, 650-1.

Tibet, Ancient folk-literature from north-eastern (F. W. Thomas), 650-1.

Tibet, Oracles and demons of (René de NebeskyWojkowitz), 649-50.

Tibetan tankas, Thirteen (Edna Bryner), 677-8.

Tibetan transcription, A note on Chinese texts in (Walter Simon), 334-43.

Tiv, The classification of verbs in (D. W. Arnott), 111-33.

TOYNBEE (ARNOLD J.), $A$ study of history. Abridgement of Vols. VII-X by D. C. Somervell, 439.

Traité juridique, Le, du 'Souei-chou' (Étienne Balázs), 651-2.

treatment, The, of opposites in Lao Tzŭ (D. C. Lau), 344-60.

Trimron (A. S.), The Old Testament in Muslim Spain, 392-5 ; Sidelights on Muslim history, 464-71 ; Materials on Muslim education in the Middle Ages, 630-1.

Trois énigmes sur les Cent Chemins. Tom. II (Armand Minard), 441-2.

Tscharner (E. H. DE), see Corbin (H.).

TUCK AR (A. N.), rev., 430-1.

Tucker (A. N.) and Bryan (M. A.), Linguistic survey of the northern Bantu borderland. Vol. four, 666-7.

Tucker (A. N.) and MpaAyei (J. Tompo OLE) A Maasai grammar, with vocabulary, 428-30. Tülünids, The coinage of the (Oleg Grabar), 631 .

tungusischen Sprachen, Die (Johannes Benzing), 642-3. 
Turk, Europe and the (Dorothy M. Vaughan), 211.

Turkic languages and literatures, The, of Central Asia (Rudolf Loewenthal), 642.

Turkish language, The, of Soviet Azerbaijan (C. G. Simpson), 439-40.

TwITCHETT (D. C.), rev., 651-7.

Two Japanese villages (Robert J. Smith and John B. Cornell), 423-4.

Two sixteenth-century Arabian geographical works (R. B. Serjeant), 254-75.

\section{$\mathbf{U}$}

Uhlen beck (E. M.), see Cense (A. A.).

ULLENDORFF (EDWARD), rev., 179-81, 431-2. unabridged English-Malay dictionary, $A n$ (Sir Richard Winstedt), 679.

Uralic languages, The form of the object in the (Bo Wickman), 416.

Usas and Mater Matuta (J. Brough), 395-9.

\section{V}

Varieties of huong-höa: a problem of Vietnamese law (Henry McAleavy), 608-19.

VARMA (K. M.), Nätya, nrtta and nrtya : their meaning and relation, 648-9.

Vasubandhus, On the theory of two (Padmanabh S. Jaini), 48-53.

VAUGHAN (DoRothy M.), Europe and the Turk : a pattern of alliances, 1350-1700, 211.

VELLa (WALTER F.), Siam under Rama III 1824-1851, 663-5.

version mone, La, du Nãrada-jātaka (ed. and tr. Pierre Dupont), 199-200.

Volkskundliche und religiōse Begriffe im nördlichen Waldland von Kamerun (Johannes Ittmann), 448.

VOORHOEVE (P.), comp., Handlist of Arabic manuscripts in the Library of the University of Leiden, 628-9.

vulgärarabische Poetik, Die, al-Kitāb al-'Atil

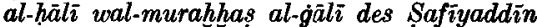
Hilli (ed. Wilhelm Hoenerbach), 405-7.
W

WACKERNAGEL (JAKOB), Altindische Grammatik. Nachträge zu Bd. II, 1 von Albert Debrunner, 440.

WaLex (ARTHUR), Yuan Mei, eighteenth century Chinese poet, 444-5.

War and peace in the law of Islam (Majid Khadduri), 438.

WARD (ROBERT E.), ed., Five studies in Japanese politics, 446.

WARDER (A. K.), rev., 195-7, 645-7.

Waropense teksten (ed. and tr. G. J. Held), 447.

Waterson (Natalie), rev., 439-40.

Watt (W. Montgomery), Muhammad at Medina, 187-8.

WhLler (Friterich), Die Legende von Sunahsepa, 675.

White (WILlam Charles), Bronze culture of ancient China, 657

WHTTELEY (W. H.), rev., 434-5.

Whither North Africa? (Nicola A. Ziadeh), 438.

WICKI (JosEF), Die Schrift des P. Gonçalo Fernandes S.J. uber die Brahmanen und Dharma-ŚSastra (Madura 1616), 213-14.

WICKMAN (Bo), The form of the object in the Uralic languages, 416.

Winstedt (Sir Richard), An unabridged English-Malay dictionary, 679.

Winston (F. D. D.), rev., 436.

WITTFOGEL (KARL A.), Oriental despotism : a comparative study of total power, 657-60.

Wolters (O. W.), Tāmbralinga, 587-607.

WU (EUGENE), Leaders of twentieth-century China: an annotated bibliography, 214.

\section{$\mathbf{Y}$}

Yadin (Yigael), see Avigad (NahmaN).

Yuan Mei, eighteenth century Chinese poet (Arthur Waley), 444-5.

\section{Z}

ZaEHner (R. C.), Mysticism, sacred and profane, 185-7.

ZradeH (NICOLA A.), Whither North Africa?, 438. 